\title{
Retraction Note: Analysis of protein-protein interaction network and functional modules on primary osteoporosis
}

\author{
Gai-Li Li ${ }^{1}$, Xian-Hua Xu' ${ }^{1}$, Bing-Ang Wang ${ }^{2 *}$, Yi-Min Yao ${ }^{2}$, Yang Qin ${ }^{1}$, Shu-Rong Bai ${ }^{1}$, Jian Rong ${ }^{1}$, Tao Deng ${ }^{1}$ \\ and Yong-He Hu${ }^{1 *}$
}

\section{Retraction}

The Publisher and Editor regretfully retract this article [1] because the peer-review process was inappropriately influenced and compromised. As a result, the scientific integrity of the article cannot be guaranteed. A systematic and detailed investigation suggests that a third party was involved in supplying fabricated details of potential peer reviewers for a large number of manuscripts submitted to different journals. In accordance with recommendations from COPE we have retracted all affected published articles, including this one. It was not possible to determine beyond doubt that the authors of this particular article were aware of any third party attempts to manipulate peer review of their manuscript.

Received: 25 January 2015 Accepted: 2 March 2015

Published online: 26 March 2015

\section{Reference}

1. Li GL, Xu XH, Wang BA, Yao YM, Qin Y, Bai SR, et al. Analysis of protein-protein interaction network and functional modules on primary osteoporosis. Eur J Med Res. 2014;19:15.

\footnotetext{
*Correspondence: bingangwang@hotmail.com; yonghehufh@hotmail.com ${ }^{2}$ Department of Orthopedics, 452 Hospital of the People's Liberation Army, Shunjiang Road, 610021 Chengdu, China

'Department of Geriatrics, Chengdu Military General Hospital, No. 270,

Rongdu Avenue, Jinniu District, 610083 Chengdu, China
}

Submit your next manuscript to BioMed Central and take full advantage of:

- Convenient online submission

- Thorough peer review

- No space constraints or color figure charges

- Immediate publication on acceptance

- Inclusion in PubMed, CAS, Scopus and Google Scholar

- Research which is freely available for redistribution 